\title{
Pengembangan Kurikulum Darurat Covid-19 (model dan media pembelajaran pada masa pandemi covid-19)
}

\author{
Mohamad Eri Hadiana, Erlita Octiana Nur'alimah \\ UIN Sunan Gunung Djati Bandung, Bandung Jawa Barat \\ Corresponding email: erihadiana@uinsgd.ac.id, erlitaoctiana96@gmail.com
}

\begin{abstract}
The existence of the corona virus outbreak has affected several sectors including the education sector. In dealing with the spread of the covid-19 virus, the government issued a distance learning policy with an emergency curriculum. The purpose of this study will discuss the models and learning media during the Covid-19 pandemic with library research sourced from research journals, the curriculum used at Al-Fatih Primary Islamic School and other literature that supports this research. The results showed that the emergency curriculum has high flexibility and provides space for educational institutions to develop the curriculum structure up to the evaluation stage. The models used during this pandemic were e-learning, blanded learning and home visits. The learning media used depend on the needs of teachers and students, including zoom, WhatsApp, and other media that can support learning online (online).
\end{abstract}

Keywords:

emergency curriculum, online learning model, learning media

\begin{abstract}
Abstrak
Adanya wabah virus corona mengakibatkan beberapa sektor terkena dampak termasuk sektor pendidikan. Dalam mengatasi penyebaran virus covid-19, pemerintah mengeluarkan kebijakan pembelajaran jarak jauh dengan kurikulum darurat. Tujuan penelitian ini akan membahas mengenai model dan media pembelajaran pada masa pandemi covid-19 dengan penelitian kepustakaan yang bersumber dari jurnal penelitian, kurikulum yang digunakan di Al-Fatih Primary Islamic School dan literatur lain yang menunjang penelitian ini. Hasil penelitian menunjukan bahwa kurikulum darurat memiliki flesibilitas yang tinggi dan memberikan ruang kepada lembega pendidikan scara luas dalam mengembangkan struktur kurikulum sampai dengan tahap evaluasi. Model yang digunakan pada masa pandemi ini yaitu e-learning, blanded learning dan home visit. Adapun media pembelajaran yang digunakan tergantung kebutuhan guru dan peserta didik, diantaranya seperti zoom, whatsapp, dan media lain yang dapat menunjang pemebalajaran secara online (daring).
\end{abstract}

Kata Kunci:

kurikulum darurat, model pembelajaran daring, media pembelajaran daring

\section{A. PENDAHULUAN}

Wabah virus covid-19, sudah tercatat kurang lebih satu tahun. Penularan virus ini sangat cepat, akibatnya pendidikan terkena dampak wabah ini. 1 Dalam mengatasi penyebaran virus tersebut terdapat kebijakan pemerintah terhadap pendidikan dalam masa darurat

\footnotetext{
${ }^{1}$ Franciscus Dwikotjo Sri Sumantyo, "Pendidikan Tinggi Di Masa Dan Pasca Covid-19," Jurnal Kajian IImiah 1, no. 1 (2020): 81-92.
}

penyebaran virus covid-19 yaitu meningkatkan peran Sekolah dalam melengkapi fasilitas pelayanan kesehatan sebagai usaha pencegahan penyebaran covid- 19, menyiapkan sarana untuk cuci tangan pakai sabun dan alat pembersih sekali pakai seperti tisu dan kain di berbagai lokasi strategis 
di satuan pendidikan, memastikan pihak Sekolah melakukan pembersihan ruangan dan lingkungan Sekolah secara rutin terutama pada fasilitas lain yang sering terpegang oleh tangan dan mengingatkan seluruh warga Sekolah untuk menghindari kontak fisik secara langsung. ${ }^{2}$ Namun, berbagai upaya yang dilakukan sesuai protokol kesehatan belum mampu mencegah penyebaran virus corona ini.

Berdasarkan Surat Edaran

Nomor 3 Tahun 2020 pada Satuan Pendidikan dan Nomor 36962/MPK.A/HK/2020 tentang Pelaksanaan Pendidikan dalam Masa Darurat Corona Virus Disease (Covid19) menyebutkan bahwa kegiatan belajar dilakukan secara daring (online) dalam rangka pencegahan penyebaran Covid19. ${ }^{3}$ Hal ini membuat pembelajaran yang tadinya tatap muka menjadi pembelajaran jarak jauh (daring). Berbagai platform online seperti WhatsApp, Google Clasroom, Google Meet, Zoom dan platforn lainnya menjadi media belajar ketika berlangsungnya pembelajaran online.

Adanya kondisi seperti ini, membuat tantangan tersendiri bagi sekolah, guru, siswa bahkan orang tua. Bukan hal mudah mengganti kebiasaan pembelajaran tatap muka menjadi jarak jauh, perlu adanya pembaruan dan adaptasi dalam melaksanakannya.

\footnotetext{
${ }^{2}$ Rahmathias Jusuf and Asri Maaku, "Kurikulum Darurat Covid 19 Di Kota Kotamobagu; Fenomena Dan Realita Guru Madrasah," Jurnal IImiah Iqra' 14, no. 2 (2020): 155-70.

${ }^{3}$ Intan Safitri Mokodompit, "Home Visit Sebagai Refleksi Kurikulum Darurat Covid-19: Kesiapan Guru, Respon Siswa, Materi Dan Hasil Belajar Di
}

Dengan keadaan pandemi seperti ini, pemerintah mengeluaran kebijakann kurikulum darurat covid-19. Berbagai model dan media pembelajaran yang dapat menunjang kebutuhan pembejaran online bermunculan seperti home visit, e-learning, blanded learning. Maka dari itu dalam penelitian ini akan dikaji mengenai metode dan media yang digunakan pada saat covid-19.

Penelitian ini menggunakan studi kepustakaan dengan tujuan mengumpulkan informasi dan data secara mendalam melalui berbagai macam literatur. Studi kepustakaan tersebut digunakan untuk menganalisis metode dan media yang digunakan pada masa covid-19 dalam penerapan kurikulum darurat. Penelitian studi kepustakaan ini memanfaatkan sumber data penelitian dari jurnal yang terindeks google schoolar, kurikulum Sekolah Al-Fatih Primary Islamic School dan berbagai literatur lain yang menunjang permasalahan dalam penelitian ini.

\section{B. HASIL DAN PEMBAHASAN}

Adanya kurikulum darurat covid-19, pada penelitian Ahmad Munajim dkk,4 tentang "pengembangan kurikulum pembelajaran di masa darurat", dibahas mengenai regulasi kurikulum darurat pada masa pandemi covid-19. Hasil dari penelitiannya

\footnotetext{
Madrasah Tsanawiyah," Dirāsāt: Jurnal Manajemen Dan Pendidikan Islam 6, no. 2 (2020): 119-31.

${ }^{4}$ Ahmad Munajim, Barnawi Barnawi, and Fikriyah Fikriyah, "Pengembangan Kurikulum Pembelajaran Di Masa Darurat," DWIJA CENDEKIA: Jurnal Riset Pedagogik 4, no. 2 (n.d.): 285-91.
} 
menunnjukan bahwa kurikulum ini memberi ruang untuk satuan pendidikan untuk mendesain kurikulum dari mulai struktur kurikulum sampai ke tahap penilaian.

1. Struktur kurikulum di masa darurat mereduksi dari kurikulum 2013 (k13) menyangkut jumlah jam mata pelajaran dan durasi waktu.

2. Pengembangan materi pelajaran di masa darurat dapat dipilih oleh guru, materi pelajaran mana yang akan menjadi prioritas dalam pembelajaran dan yang mana yang dapat dipelajari siswa secara mandiri. Materi pelajaran diperoleh dari buku-buku sumber siswa seperti buku paket, buku pedoman guru dan literatur lain yang berkaitan dengan ruang lingkup pembelajaran dan dikembangkan dengan kehidupan atau fenomena sosial yang terjadi seperti covid-19.

3. Model dan metode pembelajaran dipilih oleh guru disesuaikan dengan kondisi darurat yang memungkinkan dapat mencapai tujuan pembelajaran kemudian guru secara kreatif mengembangkan metode dan model tersebut disesuaikan dengan arakteristik materi atau tema pembelajaran.

4. Media dan sumber belajar dapat menggunakan sumber dan media apapun yang memang disesuaikan dengan kondisi darurat.

5. Perencanaan pembelajaran (RPP) harus disusun oleh guru, dalam menyusun RPP, guru harus merujuk pada SKL, KI-KD dan dan Indikator
Pencapaian yang diturunkan dari KD. Guru dapat membuat pemetaan KD dan memilih materi esensi yang akan di ajarkan kepada peserta didik pada masa darurat debab memperhatikan 3 ranah pencapaian yaitu kognitif, apektif dan psikomotorik. Dalam kodisi darurat seperti ini menteri pendidikan mengeluarkan RPP satu lembar yang hanya cukup ditulis tujuan pembelajaran, langah-langkah pembelajaran dan penilaian.

6. Kegiatan pembelajaran harus memperhatikan berbagai aspek dan regulasi salah satunya yaitu SKB 4 Menteri (menteri pendidikn, menteri Agama, menteri Kesehatan dan menteri dalam negeri). Kegiatan pembelajaran pada masa pandemi covid-19 ini dilaksanakan sesuai zona masing-masing daerah. Kondisi daerah zona hijau dapat melaksanakan pembelajaran tatap muka dengan dua fase yaitu fase transisi dan fase new normal selain itu juga harus memperhatikam protokol kesehatan dan memperoleh rekomendasi dari dinas kesehatan. Sedangkan kondisi daerah dengan zona merah, kuning dan orange tidak dapat melaksanakan pemebalajaran tatap muka. Maka dengan adanya regulasi tersebut kegiatan pemebelajaran daring dan luring sebagai solusi, diharapkan seluruh stakeholder lembaga pendidikan dpat kreatif dan inovatifdalam pemilihan media pembelajaran yang menghemat biaya tetapi pembelajaran dapat 
terlaksana secara efektiif dan efisien.

7. Bentuk penilaian hasil belajar pada masa darurat ini disesuaikan dengan kondisi infrastruktur pendukung masing-masing lembaga pedidikan.

Hasil dari penelitian tersebut, menunjukan bahwa kurikulum darurat memiliki fleksibilitas yang tinggi dan memberi ruang kepada lembaga pendidikan secara luas untuk mendesain struktur kurikulum, kegiatan pembelajaran dan media pembelajaran dengan tetap memperhatikan pengembangan pengetahuan, penguatan karakter dan peningkata keterampilan yang tentunya disesuaikan dengan kebijakan pendidikan dan mematuhi protokol kesehatan.

Dalam

pelaksanaan pembelajaran pada masa pandemi covid-19 ini, berbagai model pembelajaran untuk menunjang terlaksananya pembelajaran disajikan oleh guru, diantaranya yaitu e-learning, blanded learning dan home visit.

\section{a. E-learning}

Kegiatan pembelajaran online telah menjadi pilihan bagi lembaga sekolah dalam melaksanakan kegiatan belajar mmengajar. Dalam penelitain Dyah Darma Andayani, dkk yang berjudul "penerapan e-

${ }^{5}$ Dyah Darma Andayani, Fathahillah Fathahillah, and Nurul Mukhlisah Abdal, "Penerapan ELearning Sebagai Alternatif Pembelajaran Di Masa Pandemi Covid-19," in Seminar Nasional Pengabdian Kepada Masyarakat, 2020. learning sebagai alternatif pembelajaran di masa pandemi covid-19" .5 penggunaan e-learing pada masa pandemi menjadi alternatif terbaik karena e-learning memiliki fitur-fitur yang dapat menggntikan proses belajara mengajar di dalam kelas, kemudian e-learning dapat memberikan kemudahan akses bagi siswa untuk mencari materi pelajaran di berbagai sumber. Selain itu guru memiliki kesempatan untuk eksplorasi pemebelajarn sehingga menghasilkan produk pembelajaran yang berkualitas seperti keleluasan guru dalam menyajikan materi pembelajaran dalam media embelajaran lain seperti google classroom dan aplikasi web meeting untuk adanya timbal balik antara guru dan peserta didik meskipun keterbatasan waktu.

\section{b. Blanded learning}

Model pembelajaran blanded learning merupakan pemebelajaran campuran yang menggabungkan pembelajaran tatap muka dengan penggunaan platform media online seperti whatsapp, zoom, google meet dan media pembelAjaran lainnya. Model ini menjadi solusi dalam mengatasi masalah pembelajaran yang terkendala jarak dan waktu. ${ }^{6}$ Beberapa sekolah pada tahun ajaran 2020/2021 semester 2

\footnotetext{
${ }^{6}$ Tubagus Panambaian, “Penerapan Program Pengajaran Dengan Model Blended Learning Pada Sekolah Dasar Di Kota Rantau," Journal Analytica Islamica 9, no. 1 (2020): 52-68.
} 
ini banyak yang menggunakan pembelajaran blanded learning , model ini berbeda dengan model $e$ learning. Model pembelajaran blanded learning ini termasuk kedalam pembelajaran interaktif yang memadukan pembelajaran tatap muka dan pembelajaran daring. Ada beberapa tahapan dalam penerapan model blanded learning yaitu analisis kebutuhan (need assessment), perencanaan (planing), pembuatan dan pengembangan (developing), pelaksanaan (implementetion), evaluasi (evaluating). ${ }^{7}$

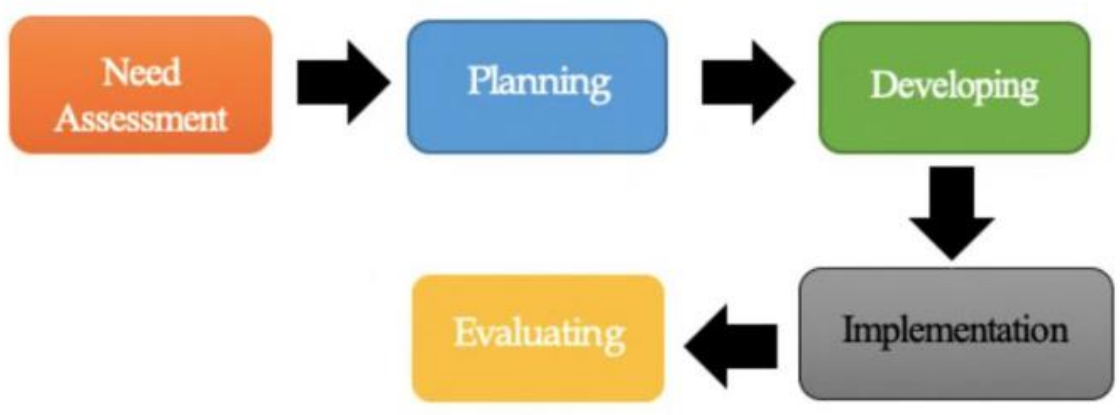

\section{Gambar Tahapan Kegiatan Blanded Learning}

Pada sekolah Al-Fatih Primary Islamic School yang bertempat di kabupaten Bandung menerapkan model pembelajaran blanded learning sebagai solusi berjalannya pembelajaran dengan mengkombinasikan pembelajaran di rumah (LFH) dengan pembelajaran tatap muka di sekolah. Pembelajaran tatap muka dilaksanakan secara bertahap, dengan artian siswa tidak melakukan pembelajaran setiap hari di sekolah namun dikombinasikan dengan learning from home (LFH). Pelaksanaan pembelajaran blanded learning ini didukung dengan persetujuan beberapa pihak, baik dari pemerintah setempat, dinas kesehatan, yayasan juga orang tua dengan memenuhi protokol kesehatan.

Pelaksanaan learning from home pada sekolah Al-Fatih, dilaksanakan dengan beberapa penyajian media belajar oleh guru seperti rekaman belajar menggunakan google classroom, video dan audio recording, link youtube dan google drive. Adapun pembelajaran interaktifnya menggunakan zoom/google meet dan evaluasi pembelajarannnya menggunakan google form, google classroom dan quizzis. Selain itu, pembelajaran di rumah juga harus

\footnotetext{
${ }^{7}$ Sri Gusty et al., Belajar Mandiri: Pembelajaran Daring Di Tengah Pandemi Covid-19 (Yayasan Kita Menulis, 2020).
} 
memenuhi adab saat belajar diantaranya memakai seragam, bersungguh-sungguh mengikuti pembelajaran, mengumpulkan tugas tepat waktu, tidak mmaikan hp saat belajar, duduk menyimak dengan baik saat zoom atau saat membalas chat dengan sopan.

\section{c. Home visit}

Home visit merupakan kegiatan pendukung bimbingan dan konselinhyng dilakukan guru dengan mengunjugi siswa di rumah. Home visit dilakukan untung mencari data terkait kondisi keluarga, fasilitas belajar serta hubungan antar keluarga yang berkaitan dengan permasalahan belajar siswa. ${ }^{8}$ Ada beberapa hal yang harus diperhatikan dalam melakukan home visit : 1) guru, orang tua, dan siswa harus mematuhi protokol kesehatan; 2) melakukan penjadwalan home visit secara berkelompok dan bergilir; 3) adanya kerja sama yang baik antara guru dan orang tua; 4) diadakannya kelas parenting bagi orang tua agar dapat menstimulasi perkembangan anak; 5) kegiatan berikutnya dilanjutkan oleh orang tua; 6) melakukan monitoring dan evaluasi.

Kegiatan home visit menjadi solusi kegiatan belajar mengajar

\footnotetext{
${ }^{8}$ Mokodompit, "Home Visit Sebagai Refleksi Kurikulum Darurat Covid-19: Kesiapan Guru, Respon Siswa, Materi Dan Hasil Belajar Di Madrasah Tsanawiyah."

${ }^{9}$ Besse Nirmala and Haerul Annuar, "Home Visit: Strategi PAUD Dari Rumah Bagi Guru Di Daerah 3T Pada Masa Pandemi Covid-19," Jurnal Obsesi:
}

dengan keterbatasan fasilitas belajara online selain itu kegiatan ini dapat memberi pengaruh positif kepada anak dala, mengembangakan prilaku, motivasi belajar an juga menigkatkan kemampuan orang tua dalam menstimulus perkembangan anaknya.9

Mengenai media pembelajaran yang digunakan pada masa darurat covid-19 ini, banyak digunakan media pembelajaran online seperti whatsapp, zoom, google classroom dan media online lain yang menunjang pembelajaran secara online. Hal ini juga dibahas dalam penelitian Lalu Gede M Zainuddin Atsani dengan jurnal yang berjudul "Transformasi Media Embelajaran Pada Masa Pandemi Covid-19".10 Hasil penelitiannya menyebutkan bahwa dengan adanya pandemi covid-19 ini pembelajaran dilaksanakan secara daring (online) yang dilaksanakan melalui perangkat personal computer (pc), laptop, smartphone yang mampu terkoneksi peda jaringan internet. Pendidik dapat melalkukan pembelajaran menggunakan aplikasi belajar online yang beragam seperti whatsapp, telegram, zoom, dan media online lainnya yang dapat dijadikan media belajar.

Jurnal Pendidikan Anak Usia Dini 5, no. 2 (2020): 1052-62.

${ }^{10} \mathrm{~K}$ H Lalu Gede Muhammad Zainuddin Atsani, "Transformasi Media Pembelajaran Pada Masa Pandemi COVID-19," Al-Hikmah: Jurnal Studi Islam 1, no. 1 (2020): 82-93. 
Dengam menggunakan media pembelajaran online tersebut pendidik dapat memastikan bahwa perserta didik mengikuti pembelajaran di waktu yang sama meskipun berada ditempat yang berbeda-beda. Guru dapat memberi tugas sesuai materi dan tujuan pembelajaran kepada peserta didik melalui media pembelajaran yang sudah disiapkan dan disepakati antara guru dan peserta didik. Namun pada penerapannya terdapat berbagai kendala yang dihadapi terutama peserta didik dalam melaksanakan pembelajaran online, seperti ketidakfahaman baik orang tua atau siswa pada pengoprasian sistem pembalajaran online, tidak semua orang tua siswa mampu membeli kuota internet, keterbatasan sinyal di daerah masing-masing, kondisi ekonomi orang tua siswa sehingga tidak mempunyai fasilitas belajar online seperti smartphone, dan kurang terkontrolnya pemeblajaran oleh guru disebabkan tidak bertatap muka secara langsung.

Berikut adalah kendala-kendala yang dihadapi dalam menggunakan media pembelajaran online :

a. Aplikasi Zoom

Menurut penelitian Andi Sahtiani Jahrir dan Muhammad Tahir tentang “Dampak Media Aplikasi Zoom Sebagai Media Pembelajaran Online Selama

\footnotetext{
${ }^{11}$ Andi Sahtiani Jahrir and Muhammad Tahir, “DAMPAK MEDIA APLIKASI ZOOM SEBAGAI MEDIA PEMBELAJARAN ONLINE SELAMA PANDEMI COVID-19," KLASIKAL: JOURNAL OF EDUCATION,
}

Pandemi Covid-19"." Dari hasil penelitiannya menunjukan bahwa dengan menggunakan aplikasi zoom terdapat beberapa kendala yaitu banyaknya penggunaan data atau kuota internet, durasi yang sempit yang hanya 40 menit membuat tidak cukupnya penyampaian mater pelajaran, sinyal yang kurang mendukung dan sulitnya pengumpulan tugas.

b. Whatsapp

Dalam keadaan pembelajaran jarak jauh karena pandemi covid-19, whatsapp banyak digunakan guru dalam berinteraksi dengan peserta didik, namun banyak kendala yang dihadapi dalam penggunaannya sebagaimana penelitian Mirzon Daheri, dkk. Tentang "efektifitas whatsapp sebagai media belajar daring". ${ }^{2}$ Pembelajaran menggunakan whatapp ini kurang efektif karena kurangnya penjelasan yang dapat dimengerti dari guru selain itu pembelajaran pun lebih mendalukan aspek kognitif saja, hal ini dilihat dari guru hanya memberikan tugas saja maka dari itu untuk aspek afektif dan psikomotoriknya sangat rendah. Kemudian kendala lainnya terdapat pada latar belakang pendidikan orang tua, kesibukan orang tua dan sinyal yang kurang memadai.

\section{SIMPULAN}

Kurikulum darurat pada masa pandemi covid-19 memiliki flesibilitas yang tinggi sehingga lembaga memiliki

LANGUAGE TEACHING AND SCIENCE 2, no. 3 (2020): 9-18.

12 Mirzon Daheri et al., "Efektifitas Whatsapp Sebagai Media Belajar Daring," Jurnal Basicedu 4, no. 4 (2020): 775-83. 
keleluasaan dalam mengembangan struktur kurikulum, kegiatan belajar dan media pembelajaran dengan memenuhi aturan protokol kesehatan. Model dan media pembelajaran yang digunakan pada saat pendemi covid-19 sangat beragam sebagai solusi dalam pelaksanaan pembelajaran. Model yang banyak digunakan yaitu e-learnig, blanded learning dan home visit. Ketiga model tersebut dapat dijadikan model pembelajaran pada masa darurat covid19 ini karena ketiganya memiliki fungsi solutif yang berbeda. Adapun dalam pelaksanaan media pembelajaran masa darurat ini banyak digunakan bebagai media online seperti whatsapp dan zoom. Dalam penggunaan media pembelajaran tersebut, banyak kendala yang dihadapi guru, siswa dan orang tua, pasalnya dengan penggunaan media pembelajaran online terkendala dari segi kebutuhan kuota internet, pemahaman pengaplikasian teknologi dan efektifitas dalam pembeljaran. Maka dalam pembelajaran masa darurat ini, banyak hal yang harus dievaluasi oleh pemerintah, lembaga, pendidik, orang tua dan juga siswa agar pembelajaran dapat mecapai tujuan pendidikan sesuai harapan.

\section{DAFTAR PUSTAKA}

Andayani, Dyah Darma, Fathahillah Fathahillah, and Nurul Mukhlisah Abdal. "Penerapan E-Learning Sebagai Alternatif Pembelajaran Di Masa Pandemi Covid-19." In Seminar Nasional Pengabdian Kepada Masyarakat, 2020.

Atsani, K H Lalu Gede Muhammad Zainuddin. "Transformasi Media
Pembelajaran Pada Masa Pandemi COVID-19." Al-Hikmah: Jurnal Studi Islam 1, no. 1 (2020): 82-93.

Daheri, Mirzon, Juliana Juliana, Deriwanto Deriwanto, and Ahmad Dibul Amda. "Efektifitas Whatsapp Sebagai Media Belajar Daring." Jurnal Basicedu 4, no. 4 (2020): 77583.

Gusty, Sri, Nurmiati Nurmiati, Muliana Muliana, Oris Krianto Sulaiman, Ni Luh Wiwik Sri Rahayu Ginantra, Melda Agnes Manuhutu, Andriasan Sudarso, Natasya Virginia Leuwol, Apriza Apriza, and Andi Arfan Sahabuddin. Belajar Mandiri: Pembelajaran Daring Di Tengah Pandemi Covid-19. Yayasan Kita Menulis, 2020.

Jahrir, Andi Sahtiani, and Muhammad Tahir. "DAMPAK MEDIA APLIKASI ZOOM SEBAGAI MEDIA PEMBELAJARAN ONLINE SELAMA PANDEMI COVID-19." KLASIKAL: JOURNAL OF EDUCATION, LANGUAGE TEACHING AND SCIENCE 2, no. 3 (2020): 9-18.

Jusuf, Rahmathias, and Asri Maaku. "Kurikulum Darurat Covid 19 Di Kota Kotamobagu; Fenomena Dan Realita Guru Madrasah.” Jurnal Ilmiah Iqra' 14, no. 2 (2020): 155-70. Mokodompit, Intan Safitri. "Home Visit Sebagai Refleksi Kurikulum Darurat Covid-19: Kesiapan Guru, Respon Siswa, Materi Dan Hasil Belajar Di Madrasah Tsanawiyah.” Dirāsāt: Jurnal Manajemen Dan Pendidikan Islam 6, no. 2 (2020): 119-31.

Munajim, Ahmad, Barnawi Barnawi, and Fikriyah Fikriyah. "Pengembangan Kurikulum Pembelajaran Di Masa Darurat." DWIJA CENDEKIA: Jurnal Riset Pedagogik 4, no. 2 (n.d.): 285-91. 
Nirmala, Besse, and Haerul Annuar. "Home Visit: Strategi PAUD Dari Rumah Bagi Guru Di Daerah 3T Pada Masa Pandemi Covid-19." Jurnal Obsesi: Jurnal Pendidikan Anak Usia Dini 5, no. 2 (2020): 105262.

Panambaian, Tubagus. "Penerapan Program Pengajaran Dengan Model
Blended Learning Pada Sekolah Dasar Di Kota Rantau." Journal Analytica Islamica 9, no. 1 (2020): 52-68.

Sumantyo, Franciscus Dwikotjo Sri. "Pendidikan Tinggi Di Masa Dan Pasca Covid-19." Jurnal Kajian Ilmiah 1, no. 1 (2020): 81-92. 